\title{
Protein/Amino Acid Biochemistry, Degradation and Protease Chemistry
}

National Cancer Institute

\section{Source}

National Cancer Institute. Protein/Amino Acid Biochemistry, Degradation and Protease

Chemistry. NCl Thesaurus. Code C18972.

The study of the molecules and mechanisms involved in the metabolism of proteins and amino acids with an emphasis on their processing and degradation. 